\title{
32. パルス放電におけるキセノンの真空紫外放射特性
}

\author{
池田善久* 黒河久悦 本村英樹 青野正明 \\ (愛媛大学)
}

\section{1 はじめに}

キセノン封入放電管をパルス放電させるとき、原子共鳴放射と工 キシマ放射に及ぼすキセノン封入圧力の影響を求めた。

\section{2 実験方法}

キセノンの封入圧力が 10Torr、50Torr および 100Torr の 3 種類 の放電管を外部電極を用いてパルス放電 (周波数 $10 \mathrm{kHz}$ 、パルス幅 $10 \mu \mathrm{sec})$ させた。管電流のピーク值を $1 \mathrm{~mA}$ から $3 \mathrm{~mA}$ まで変えたと きの、キセノンの原子共鳴放射 $147 \mathrm{~nm}$ とエキシマからの放射 $172 \mathrm{~nm}$ の放射強度の時間的変化を測定した。これら波形の時間積分から放射 強度を求めた。また、減衰の初期部分の波形を指数関数 $I=I_{\mathrm{o}} \mathrm{e}^{-t / \tau}$ により近似し、減衰時定数 $\tau$ を計算した。

\section{3 実験結果及び考察}

図 1 に封入圧力 100 Torr の放電管を管電流 $3 \mathrm{~mA}$ で放電させた場 合の $147 \mathrm{~nm}$ と $172 \mathrm{~nm}$ の放射強度の時間的変化を示す。電圧パルス の 1 周期内に、 $147 \mathrm{~nm}$ と $172 \mathrm{~nm}$ のスペクトルは、ともに電圧パル スの立ち上がり時 (第 1 放射) と、立ち下がり時 (第 2 放射) の 2 回放 射する。 $172 \mathrm{~nm}$ の放射は $147 \mathrm{~nm}$ の放射より約 $0.8 \mu \mathrm{sec}$ 遅れてピーク に達する。また $172 \mathrm{~nm}$ の放射は、 $147 \mathrm{~nm}$ の放射に比べて第 1 ピー クに対する第 2 ピークの強度比が大きい。

図 2 に放射強度と圧力の関倸を管電流をパラメータにして示す。 $147 \mathrm{~nm}$ の放射強度は、管電流が $1 \mathrm{~mA}$ と $2 \mathrm{~mA}$ のときは 50Torr のと きに最大となるが、3mA のときは10Torr のときに最大となる。こ れは管電流が大きくなるにつれて第 2 の放射が強くなるためであ る。このことは 50Torr 管と 100Torr 管の場合も同様である。一方、 $172 \mathrm{~nm}$ の放射強度は圧力が高くなるほど強くなる。また $147 \mathrm{~nm}$ と 同様に、管電流を増加すると第 2 の放射強度が相対的に強くなる。 次に放射の減衰時定数 $\tau$ と圧力との関係を、管電流が $2 \mathrm{~mA}$ の場 合について図 3 に示す。封入圧力が高くなるにつれ $\tau$ が小さくなる。 $147 \mathrm{~nm}$ はキセノンの共鳴励起原子 $\mathrm{Xe}^{*}(\mathrm{res})$ から、 $172 \mathrm{~nm}$ は準安定 原子 $\mathrm{Xe}^{*}(\mathrm{met})$ と基底原子 $\mathrm{Xe}$ の 3 体衝突を経て得られるキセノン エキシマから放射されるが、封入圧力が高くなると、 $\mathrm{Xe}^{*}(\mathrm{res})$ およ び $\mathrm{Xe}^{*}(\mathrm{met})$ が基底原子 Xe との衝突確率が増加して、これら励起 原子の消失が速くなるためである。

\section{4 まとめ}

キセノンの封入圧力が高くなるほどエキシマからの放射が強くな り、また放射の減衰が速くなる。また、管電流が大きくなるにつれ て、第 1 の放射強度に対して第 2 の放射強度が相対的に強くなる。

\section{参考文献}

[1] P. K. Leichner : Phys.Rev.A, Vol.13, No.5, p.1787 (1976)

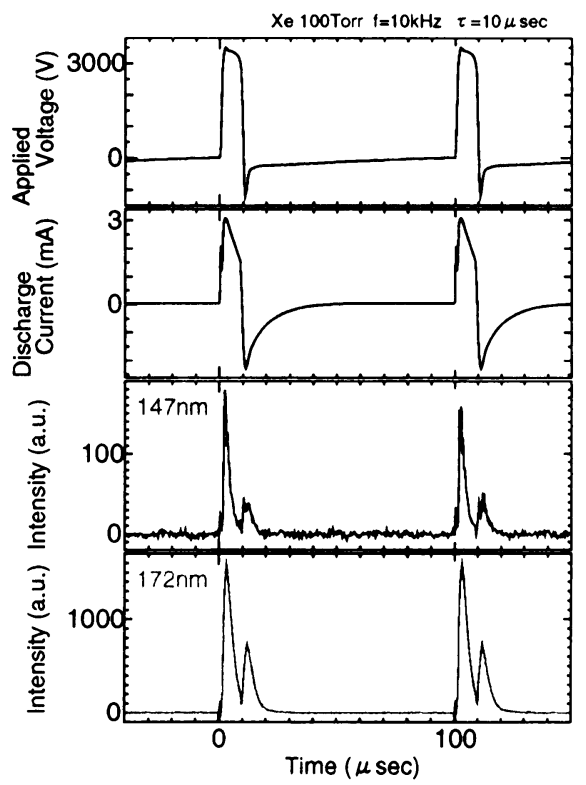

図 $1:$ 放射強度の時間的変化

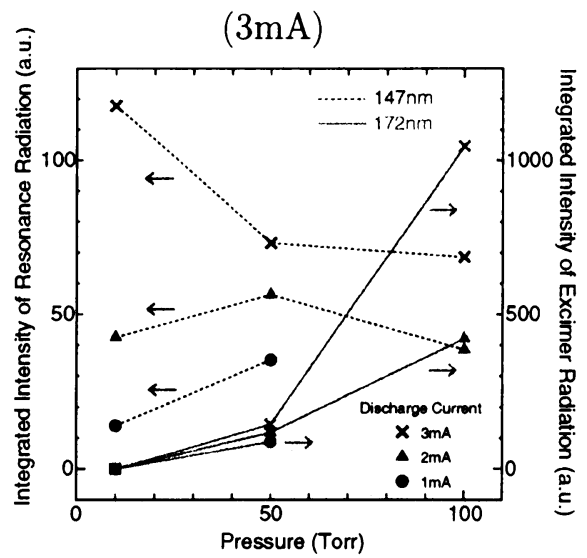

図 $2:$ 放射強度と封入圧力の関係

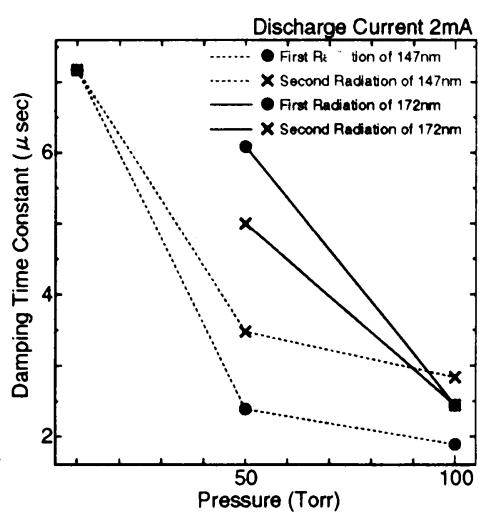

困 3 : 減衰時定数と封入圧力の 関係

Characteristics of xenon VUV radiation at pulsed discharge

Yoshihisa Ikeda, Hisanori Kurokawa, Hideki Motomura, Masaharu Aono 